Association for Information Systems AIS Electronic Library (AISeL)

ACIS 2004 Proceedings

Australasian (ACIS)

December 2004

\title{
What Motivates Software Crackers?
}

Sam Cruise

Australian National University

Sigi Goode

Australian National University

Follow this and additional works at: http://aisel.aisnet.org/acis2004

\section{Recommended Citation}

Cruise, Sam and Goode, Sigi, "What Motivates Software Crackers?" (2004). ACIS 2004 Proceedings. 118.

http://aisel.aisnet.org/acis2004/118

This material is brought to you by the Australasian (ACIS) at AIS Electronic Library (AISeL). It has been accepted for inclusion in ACIS 2004

Proceedings by an authorized administrator of AIS Electronic Library (AISeL). For more information, please contact elibrary@aisnet.org. 


\title{
What Motivates Software Crackers?
}

\author{
Sam Cruise \\ Sigi Goode \\ School of Business and Information Management \\ The Australian National University \\ Canberra, ACT \\ Email: sigi.goode@anu.edu.au
}

\begin{abstract}
Software piracy is a problem in the software industry, as firms lose revenue when pirated rather than original software is purchased. However, much of the research literature focuses on end-user piracy. This study goes directly to the initial software crackers to determine why they invest their skill in this activity instead of more lucrative and legal employment. The study applies a framework developed from the psychology literature in an online survey. The challenge of removing copy protection was the strongest motivation. Desire for social participation, while rewarding, was unimportant to crackers. Higher social status is a by-product of cracking.
\end{abstract}

\section{Keywords}

Software cracking, piracy, personal motivation

\section{INTRODUCTION}

Software, as a digital good, is expensive to produce but inexpensive to duplicate and distribute (Gopal and Sanders 2000). It is in the software producers' interests to make it as difficult as possible to obtain illegal copies of copyrighted software (Maude and Maude 1984). The role of the "cracker" in the distribution of illegal software is pivotal, since software cannot be illegally copied or used while copy protection is in place. Companies spend substantial resources developing methods to prevent unauthorised duplication (Schildkraut and Gasper 2000, Moore 2003). Removing copy protection is difficult and time-consuming, as the cracker has to circumvent, usually without the benefits of seeing the program source code, the devices developed by paid software authors. Additionally, evidence from the popular media suggests that crackers are not paid for their work (Piazza 2002). Crackers also violate software copyright legislation and software licenses (Lee 2002).

Two factors motivate this study. First, substantial funds are at stake. The business PC application software industry accounted for worldwide revenues of US\$21.6 billion in 1999 (SIAA 2000), a 19\% increase from 1998. In 1999, the estimated losses due to software piracy were US\$12.2 billion worldwide in the business software sector alone, an $11 \%$ increase from the previous year. Software authors must devise more complex means of protecting their software. Managers suffer losses as fewer software units are sold and policy developers must spend resources stopping the supply of pirated software. Second, there has been much research into why endusers use pirated software, but little attempt to understand the motivations of the individuals who initiate the spread of this software. The dearth of literature makes for a particularly intriguing study.

This discussion suggests two research questions. The apparently time-consuming and difficult tasks performed by software crackers raise the question of what motivates a cracker. This study also explores how individuals neutralises the social controls that otherwise inhibit deviant behaviour (Sykes and Matza 1957).

1. What factors motivate software crackers to remove copy protection from commercial software?

2. What factors do software crackers use to justify removing the copy protection from commercial software?

The rest of this paper is structured as follows. The next section discusses the software piracy literature. This is followed by the theoretical framework, which comprises research literature on motivation and justification, producing factors to proxy for both personality aspects. The paper then details the research method and results. Finally, discussion, conclusions and areas for further research are covered.

\section{PIRACY AND MOTIVES}

Software piracy is "the unauthorized copying of computer software, which constitutes copyright infringement, for either commercial or personal use” (SIAA 2000). Research has focused on end-user piracy (Simpson et al. 1994, Gopal and Sanders 1998, Limayem et al. 1999). Figure 1 describes the software piracy process and the pivotal role that crackers play therein. The literature profiles the typical computer criminal as young, skilled, knowledgeable, overqualified for their position, elitist, and believing that their use of the computer did not harm anyone who couldn't afford or didn't deserve to be harmed (Highland 1984). Females and older individuals are less likely to use pirated software (Solomon and O'Brien 1991, Simpson et al. 1994). A formal code of ethics, such as at a place of business, may affect an individual's decision to pirate software (Pierce and Henry 1996). However, more informal codes appear significantly less influential (Pierce and Henry 1996). Limayem et al. 
(1999) found no significant difference in attitude towards software piracy between those who attended an ethics course and those who did not.

Inadequate time to acquire software or not knowing where to obtain legitimate software, and personal gain factors, such as the challenge of piracy, affect an individual's decision to copy software (Simpson et al. 1994). This may be due to "deindividuation", the feeling of anonymity and distance from the adverse effects of their actions (Loch and Conger 1996). Crackers may see themselves as aiding others by providing free software, (consistent with Glass and Wood 1996) in the desire to help strangers (Constant et al. 1996). There is evidence that pirates earn no money from piracy (Piazza 2002). Instead the activity is a social experience, motivated by competition, prestige, and the entertainment value of distributing pirated goods (Lee 2002).

Figure 1: The Pirated Software Distribution Process

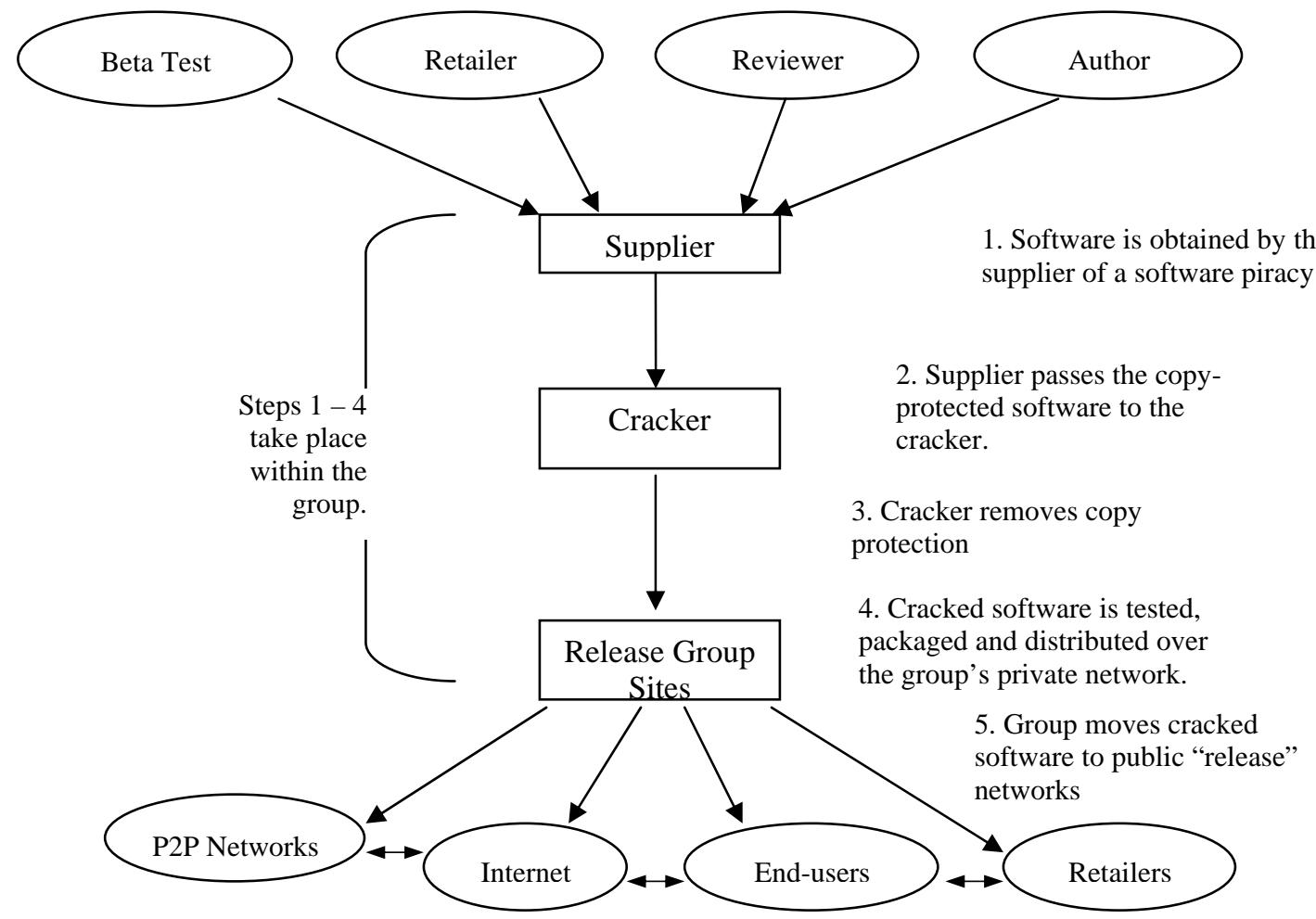

This study divides its analytical framework into theories of motivation and theories of justification (or social neutralisation). Motives are the basic causes and determinants of all behaviour which is not haphazard, trivial, or purely habitual, and is divided into two broad categories (Ford 1992). This study considers motivation where the individual is clearly conscious of a definite goal to which they are directed (Vernon 1969). Motivation can be externally based when the individual seeks affirmation of values (Barnard 1938). Individuals may aim to gain group acceptance (Katz and Kahn 1966) and, subsequently, status (Barbuto and Scholl 1998). In addition, they may set internal standards of values that become the basis for the 'ideal' self (Barbuto and Scholl 1998). Other studies addressing this 'actualization' (Maslow 1943) describe the need for achievement (McClelland 1961) and growth needs associated with developing one's potential (Alderfer 1969).

Intrinsic motivation exists where the activity itself is the incentive (Deci 1975). Intrinsically motivated behaviour is of two kinds. First, an individual may behave in ways which allow them to feel competent and self-determining (Barbuto and Scholl 1998). Second, the individual may aim to meet a challenge to gain personal achievement (Deci 1975). The greater the difficulty, the greater the motivation to succeed (Locke 1968). Knowledge gained from the challenge may itself be rewarding and hence motivating to an individual (Maslow 1943).

While evidence has suggested that crackers are not paid for their activities (Lee 2002), there is no conclusive proof that this is the case. Rewards such as salary or bonuses motivate individuals (Barnard 1938, Katz and Kahn 1966). This is similar to the need for power (McClelland 1961), safety (Maslow 1943) or the later stages of existence needs (Alderfer 1969). Figure 2 describes the motivation factors extracted from the literature review.

Figure 2: Factors of Motivation in the Context of Software Piracy

\begin{tabular}{|l|l|}
\hline Factor & Description \\
\hline $\begin{array}{l}\text { Desire for social } \\
\text { participation }\end{array}$ & $\begin{array}{l}\text { Individuals may have a need to interact socially (Maslow 1943) or be part of a group (Ashforth } \\
\text { and Mael 1989. Crackers may find the social participation of piracy rewarding (Lee 2002). }\end{array}$ \\
\hline $\begin{array}{l}\text { Desire for personal } \\
\text { challenge }\end{array}$ & $\begin{array}{l}\text { If copy protection removal is difficult, then the challenge may itself be a motivating factor for } \\
\text { crackers (Deci 1975), consistent with related psychological theories (Lee 2002). }\end{array}$ \\
\hline Desire for social status & $\begin{array}{l}\text { Competition between groups (Lee 2002) and the behaviour of individuals inside groups to seek } \\
\text { status (Barbuto and Scholl 1998) suggests that this may be a motivating factor. }\end{array}$ \\
\hline
\end{tabular}




\begin{tabular}{|l|l|}
\hline Tangible reward & $\begin{array}{l}\text { Individuals may be motivated when they perceive their behaviour will lead to tangible outcomes } \\
\text { such as pay or bonuses (Barnard 1938, Katz and Kahn 1966). }\end{array}$ \\
\hline $\begin{array}{l}\text { Demand for free } \\
\text { software }\end{array}$ & $\begin{array}{l}\text { Altruism increases the likelihood of people providing software for illegal copying (Glass and } \\
\text { Wood 1996) and provision of assistance to strangers for no tangible reward (Constant et al. 1996). }\end{array}$ \\
\hline $\begin{array}{l}\text { Personal need for free } \\
\text { software }\end{array}$ & $\begin{array}{l}\text { Financial constraints can be a motivating factor for end-users to pirate software (Simpson et al. } \\
1994, \text { Glass and Wood 1996). }\end{array}$ \\
\hline
\end{tabular}

When behaviour is deviant, it is necessary to understand how the individual neutralised the social controls that would otherwise inhibit this deviance. The techniques of neutralisation (Sykes and Matza 1957) are a popular means of exploring behaviour, and have been useful in white collar crime (Gauthier 2001). Lim (2002), in an IS context, examined neutralization in the context of employees using their company's Internet access for personal purposes. Sykes and Matza (1957) identify the denial of responsibility, denial of injury, denial of the victim, condemning the condemner and the appeal to higher loyalties.

\section{RESEARCH METHOD}

Amid the research methods available to the IS researcher, the survey has been an effective means of gathering data. The approach has received substantial literature attention (Cheyne and Ritter 2001, Nosek et al. 2002), is useful in the early stages of research (Malhotra and Grover 1998) and a range of variables can be examined in situ with little time (Malhotra and Grover 1998). However, the survey method only portrays affairs at a single point in time, provides little insight into causal relationships, and is open to bias (Galliers 1992). The immediacy and effectiveness of the survey method was deemed to outweigh these potential disadvantages. An electronic survey was deemed the most suitable research approach.

Poorly-constructed surveys can compromise otherwise sound research (Straub 1989). Survey structure was important as data had to be gathered from a variety of individuals. Where possible, questions were adapted from existing instruments (such as Solomon and O'Brien 1991). The exploratory nature of this research meant that existing questions for some factors could not be found, and new questions were developed. These questions were subjected to extensive pre-testing. Each factor was mapped to one or more questions in the instrument. Questions comprised closed-ended, seven point Likert scale items and 16 open-ended items.

The survey had to be anonymous as the identity of an individual can not be ethically sought when they may admit to criminal activity. Demographic data were collected only in relation to age, education level reached, and area of employment as in past studies of online subcultures (Highland 1984). Demographic questions were optional so as to allay fears about data misuse and hopefully increase response rates (Kotulic and Clark 2004).

Pre-testing allowed the researchers to examine the survey's functionality (Dillman 1978). The survey was tested on two crackers, known personally to the researchers. Problems with grammar and structure were addressed. A final version of the survey instrument was created based on this pilot test. A list of potential respondent questions and appropriate answers regarding research aims and the identity of the researcher was produced so that each respondent would receive the same information (Dillman 1978).

In online surveys respondents must be appropriately selected (Cheyne and Ritter 2001). Individuals may exhibit lower social desirability bias when responding to online surveys compared to paper-based surveys (Cheyne and Ritter 2001, Lim 2002). In order to limit problems such as subjects forwarding the survey to others (Simsek and Veiga 2001) and multiple responses from a single individual (Smith and Leigh 1997), participants were solicited at five known cracking forums (Simsek and Veiga 2001). Participants responded to an email address and were issued a survey, was accessible as both a text document, an attachment to the email, or a hyperlink. The webbased survey was only accessible via a one-off password in the email.

\section{RESULTS AND ANALYSIS}

A total of 28 people replied to the posts in the cracking forums to participate in the survey. From these, 26 responses to the survey were received. Of these, two were judged hostile or incomplete (more than five unanswered questions), leaving 24 usable responses.

Table 1: Factors of Motivation

\begin{tabular}{|c|c|c|c|c|}
\hline Factor & Indicator Question & Median & Mean & Std.Dev \\
\hline \multirow{2}{*}{$\begin{array}{l}\text { Desire for Social } \\
\text { Participation }\end{array}$} & The social aspects of the cracking scene are highly rewarding. & 5 & 4.58 & 1.840 \\
\hline & I would crack software even if it was not done in a group environment. & 7 & 6.33 & 1.404 \\
\hline \multirow[t]{2}{*}{$\begin{array}{l}\text { Desire for Personal } \\
\text { Challenge }\end{array}$} & $\begin{array}{l}\text { Even if I was not able to release the software I would still crack software just for the } \\
\text { challenge it involves. }\end{array}$ & 7 & 6.17 & 1.239 \\
\hline & $\begin{array}{l}\text { Cracking a piece of software is more enjoyable if the copy protection is particularly } \\
\text { difficult to remove. }\end{array}$ & 7 & 6.46 & 1.414 \\
\hline \multirow[t]{2}{*}{$\begin{array}{l}\text { Demand for Free } \\
\text { Software }\end{array}$} & $\begin{array}{l}\text { The demand for free software is an important factor in my decision to continue } \\
\text { cracking. }\end{array}$ & 1 & 2.17 & 1.736 \\
\hline & People should pay for software that they use. & 6 & 5.67 & 1.523 \\
\hline \multirow{2}{*}{$\begin{array}{l}\text { Personal Need for Free } \\
\text { Software }\end{array}$} & I only crack software that I need personally. & 1.5 & 2.21 & 1.560 \\
\hline & $\begin{array}{l}\text { I would pay for software when I could download a fully functional, cracked version } \\
\text { for free. }\end{array}$ & 4.00 & 3.75 & 2.289 \\
\hline
\end{tabular}




\begin{tabular}{|l|l|l|l|}
\hline Desire for Social & I would crack software even if I had to do it anonymously. & 7 & 6.63 \\
\cline { 2 - 4 } Status & Getting recognition for cracking software is important. & 0.924 & 2.5 \\
\hline Tangible Reward & $\begin{array}{l}\text { Tangible reward (monetary or otherwise) is the driving force behind my decision to } \\
\text { crack software. }\end{array}$ & 1 & 2.239 \\
\hline
\end{tabular}

While free software and the social aspects of cracking are rewarding, they are not motivating factors. Crackers also enjoy copy protection which is particularly difficult to remove. Cracking software transcends releasing the software publicly. Crackers believe people should pay for software they use but do not limit themselves to cracking software that they need. Recognition for cracking software and tangible rewards were not motivators.

Table 2: Factors of Justification

\begin{tabular}{|c|c|c|c|c|}
\hline Factor & Indicator Question & Median & Mean & Std.Dev \\
\hline \multirow[t]{3}{*}{$\begin{array}{l}\text { The Denial of } \\
\text { Responsibility }\end{array}$} & $\begin{array}{l}\text { The disapproval of the commercial software industry has little or no influence on my } \\
\text { decision to crack software. }\end{array}$ & 6.5 & 5.62 & 1.837 \\
\hline & $\begin{array}{l}\text { The disapproval of the law enforcement agencies has little or no influence on my } \\
\text { decision to crack software. }\end{array}$ & 6.5 & 5.46 & 2.146 \\
\hline & The actions of others forced me into cracking software. & 1 & 2.46 & 2.146 \\
\hline \multirow[t]{2}{*}{ The Denial of Injury } & No-one is really hurt as a result of software piracy. & 3 & 3.38 & 1.789 \\
\hline & Cracking software has a significant, adverse effect on the software industry. & 5 & 4.33 & 1.810 \\
\hline \multirow[t]{2}{*}{ Denial of the Victim } & The software industry does not deserve to have its product illegally copied. & 5 & 4.79 & 1.841 \\
\hline & The software industry has no right to complain about the actions of software crackers. & 3 & 3.25 & 1.894 \\
\hline \multirow{2}{*}{$\begin{array}{l}\text { Condemnation of the } \\
\text { Condemners }\end{array}$} & I hope that the software industry is not adversely affected by my actions. & 5 & 4.92 & 2.020 \\
\hline & The software industry is a bunch of hypocrites who deserve everything they get. & 4 & 3.29 & 1.756 \\
\hline \multirow{4}{*}{$\begin{array}{l}\text { The appeal to higher } \\
\text { loyalties }\end{array}$} & People that cannot afford a piece of software should not have access to it. & 2.5 & 2.92 & 1.863 \\
\hline & My actions as a software cracker constitute a service to the community at large. & 4 & 3.54 & 2.226 \\
\hline & People should have to pay for software. & 5 & 4.54 & 1.817 \\
\hline & $\begin{array}{l}\text { The benefits of my actions, as a software cracker, to the public justify the costs to the } \\
\text { software developers. }\end{array}$ & 4 & 4.00 & 1.865 \\
\hline
\end{tabular}

Piracy countermeasures have little influence on the decision to crack software. Crackers have limited sympathy for the software industry, however some believe the industry does not deserve to have their product copied.

\section{ANALYSIS OF OPEN-ENDED RESPONSES}

The 16 open-ended questions were analysed using open coding, an analytic process through which concepts and their properties are identified in the data. This process involves creating a dictionary of key concepts in the responses. From this dictionary, concepts that stand for phenomena are created (Strauss and Corbin 1998). The tables below show, for each item, the concept and its frequency. Sample responses are included to clarify meaning.

Table 3: Desire for Social Participation (Item 1)

\begin{tabular}{|l|l|}
\hline Do you find the existence of competition between release groups a compelling reason to crack software? Please explain your answer. \\
\hline Concept & Example \\
\hline Counter-productive (7) & $\begin{array}{l}\text { "Cracking groups should work together" } \\
\text { "Just cracking to get releases takes away the fun for me" }\end{array}$ \\
\hline Competitive challenge (6) & $\begin{array}{l}\text { "it’s always fun to race a big title and win. Gives you a feeling of 'we are the best”" } \\
\text { "Competition makes you push hard, get faster and code more astonishing things" }\end{array}$ \\
\hline Not part of a group (6) & $\begin{array}{l}\text { "I don't care about other groups or their individuals" } \\
\text { "I try to stay away from release groups and things of that nature" }\end{array}$ \\
\hline Promotes incompetence (2) & $\begin{array}{l}\text { "promotes the release of nonworking cracks" } \\
\text { "can make less experienced group to release fast and not check the quality of their work" }\end{array}$ \\
\hline Outgrow groups (2) & $\begin{array}{l}\text { "when you develop a serious interest in software reversing, groups become a drag and they restrict you from } \\
\text { being able to share information" }\end{array}$ \\
\hline Within-group competition (1) & $\begin{array}{l}\text { "It's always fun to release more then the other members, to make more keygens and be on the top of all the } \\
\text { team stats" }\end{array}$ \\
\hline
\end{tabular}

Table 4: Desire for Social Participation (Item 2)

Does your relationship with other members of the group exist outside of software piracy? If so, in what capacity?

\begin{tabular}{|l|l|}
\hline Concept & Example \\
\hline $\begin{array}{l}\text { Discussion not limited to piracy } \\
\text { (13) }\end{array}$ & $\begin{array}{l}\text { "it's impossible to talk with people only about software protections." } \\
\text { "I have developed friendships with people I’ve met in the cracking scene that extend outside the realm of } \\
\text { cracking software” }\end{array}$ \\
\hline Close-friendship (7) & $\begin{array}{l}\text { "The people I met through cracking have become extremely close friends to me over the years" } \\
\text { "sure, in the 'scene' you can meet some really amazing people with equal interests” }\end{array}$ \\
\hline Real-Life social interaction (6) & $\begin{array}{l}\text { "Igroup name] have had cracking LAN's where we met each other and spent 3 days together" } \\
\text { "I know many people from my own group, we met a few times together...drinking beer, vodka" }\end{array}$ \\
\hline Discussion limited to piracy (5) & $\begin{array}{l}\text { "Nope, I don't even know some of their real names, and we keep it that way" } \\
\text { "No, for security reasons you have to be very discrete” }\end{array}$ \\
\hline Constant communication (4) & "I speak to [them] on irc or phone every day" \\
\hline
\end{tabular}


Six respondents who stated that the competition between groups was counter-productive were not in groups. Most crackers' relationships with other crackers extends beyond cracking. Only 25\% of all respondents had even met members of their group in real life.

Table 5: Demand for Free Software

\begin{tabular}{|c|c|}
\hline Should all software be free? Pl & plain your answer. \\
\hline Concept & Example \\
\hline Software need not be free (20) & $\begin{array}{l}\text { "No. Software developers must be supported through the purchase of software" } \\
\text { "No. A professional has the right to ask for money in exchange of his job" } \\
\text { "Of course not, development companies wouldn't be able to support themselves" }\end{array}$ \\
\hline $\begin{array}{l}\text { Software companies over- } \\
\text { charge (10) }\end{array}$ & $\begin{array}{l}\text { "The big companies...charge too much for their products, especially with an upgrade every } 6 \text { months or year" } \\
\text { "I do think that much commercial software is ridiculously overpriced" } \\
\text { "Some programmers produce absolute crap and expect 100's of dollars for it" }\end{array}$ \\
\hline $\begin{array}{l}\text { Only pay for worthy software } \\
\text { (7) }\end{array}$ & $\begin{array}{l}\text { "I support software which I would like to use and think is reasonably price" } \\
\text { "I use WinRar, mIRC and FlashFXP a lot, I will buy them all because I use them on a regular basis and the } \\
\text { price is acceptable" }\end{array}$ \\
\hline $\begin{array}{l}\text { Poor should not be denied } \\
\text { access ( } 7 \text { ) }\end{array}$ & $\begin{array}{l}\text { "when we look at expensive software, like } \$ 5000 \text {, lets say 3D studio Max, ... NO ONE below the age } 25 \text { will } \\
\text { ever have the money to pay for such a license, should that mean the person has to wait } 10 \text { years before he can } \\
\text { start practise on 3D modelling?” } \\
\text { "Software should be available to all, more so in developing countries where the cost of some software is the } \\
\text { equivalent of a year or more’s wages" }\end{array}$ \\
\hline Donation-based software (2) & $\begin{array}{l}\text { "I believe that donation-based open source is the answer to this issue, for all digital medium (music, books, } \\
\text { software)" } \\
\text { "I often donate to authors who use a donation-based approach even if I don't use their software, just to support } \\
\text { the effort" }\end{array}$ \\
\hline All software should be free (1) & “Sure, why not- often share or trial versions are so restricted it’s impossible to properly use and appraise it” \\
\hline
\end{tabular}

This evidence suggests that crackers do not mind paying for commercial software. However, they note that the situation in which the software is purchased, and the software quality should determine the cost of the software. Table 6: Desire for Social Status (Item 1)

\begin{tabular}{|c|c|}
\hline Concept & Example \\
\hline Afforded more respect (9) & “I have a somewhat ‘high’ status in a sense, as I am real popular amongst my fellow crackers” \\
\hline Crackers are elite (7) & $\begin{array}{l}\text { "The groupie mentality kicks in and the people that DON'T know you treat you as a demi-god” } \\
\text { "Sometimes when ppl come in to my channels on IRC, they talk to me like I’m 'god almighty”” } \\
\text { "Yes. When you have a high status on the net, people know you. Admire you.” }\end{array}$ \\
\hline Status is unnecessary (7) & $\begin{array}{l}\text { “There is some respect for a crack but it’s not a motivator” } \\
\text { "It's rather fun to go onto IRC and have people message you with 'I’M YOUR BIGGEST FAN!' but I don’t } \\
\text { really use it as a motivation” }\end{array}$ \\
\hline Name is recognised (7) & $\begin{array}{l}\text { "My experience in the reverse engineering scene does give me the power of name recognition" } \\
\text { "People in the scene recognize me but people don't come falling at my feet" }\end{array}$ \\
\hline Access to restricted goods (5) & $\begin{array}{l}\text { "I can get some things which are, for others, not accessible" } \\
\text { "You get access to non-public tutorials, tools, warez and so on" }\end{array}$ \\
\hline Educator status (2) & $\begin{array}{l}\text { "The only 'higher’ status I get is when I help someone who has less knowledge about cracking or reverse } \\
\text { engineering” } \\
\text { "If you have a lot knowledge then people look up to you to learn more things for themselves” }\end{array}$ \\
\hline
\end{tabular}

Table 7: Desire for Social Status (Item 2)

\begin{tabular}{|l|l|}
\hline \multicolumn{2}{|l|}{ Should other people be grateful to you for providing cracked software? Why / why not? } \\
\hline Concept & Example \\
\hline Gratitude does not matter (11) & $\begin{array}{l}\text { "I don't crack to make other people happy" } \\
\text { "The last thing I care about while I'm cracking is the general public" } \\
\text { "I do it for fun and for my own pleasure” } \\
\text { "I crack software for fun mostly, not for people" }\end{array}$ \\
\hline $\begin{array}{l}\text { "Yes they should...One minute and they have what they wanted. And who gave them these great services? The } \\
\text { crackers" } \\
\text { "Of course they should, many 'leechers' don't care about the time we spend on a protection" } \\
\text { "I guess they should be grateful if I crack something they request" }\end{array}$
\end{tabular}

While crackers do signal that they enjoy higher status (in differing degrees) in the piracy environment, some respondents also noted that status was not needed. Higher status is a by-product of cracking but not a motivating factor.

Table 8: Desire for Personal Challenge

Is the difficulty of cracking software a compelling reason to continue the activity? Please explain your answer. 


\begin{tabular}{|c|c|}
\hline Concept & Example \\
\hline Challenge is critical (19) & $\begin{array}{l}\text { "I know of no cracker who does not enjoy the challenge" } \\
\text { "If there was no challenge then it would become just as boring as playing tic-tac-toe" }\end{array}$ \\
\hline $\begin{array}{l}\text { Experience leads to desiring } \\
\text { less challenge (6) }\end{array}$ & $\begin{array}{l}\text { "In the early days I could spend several weeks on a super hard crack. Now I try to avoid those” } \\
\text { "However, I began to get that 'rush’ [from cracking] less and less as I became a more experienced programmer” } \\
\text { "I don’t like to struggle too much...I’m not that patient anymore” }\end{array}$ \\
\hline $\begin{array}{l}\text { The harder the challenge the } \\
\text { better (6) }\end{array}$ & $\begin{array}{l}\text { "When you crack really hard software you feel like you are in heaven" } \\
\text { "The harder the challenge the more gratification one gets when finished and the more addictive it becomes" } \\
\text { "Cracking simple software is no fun" }\end{array}$ \\
\hline $\begin{array}{l}\text { New protections are the most } \\
\text { fun (5) }\end{array}$ & $\begin{array}{l}\text { "Cracking difficult software is the ultimate fun - especially when the protection is something new and elegant" } \\
\text { "If there were no new protections it would get rather boring" }\end{array}$ \\
\hline Copy Protection is futile (1) & $\begin{array}{l}\text { "It's not the difficulty that keeps us going, it's the fact that we can say, look, its pointless trying to protect [your } \\
\text { software]" }\end{array}$ \\
\hline
\end{tabular}

The challenge of cracking is clearly a significant motivation for crackers but although the difficulty of cracking was initially a motivating factor, its effects diminished as programming experience increased.

Table 9: Personal Need for Free Software

\begin{tabular}{|l|l|}
\hline How often do you pay for your own software? \\
\hline Boncept & Example \\
\hline Rarely pay for software (8) & $\begin{array}{l}\text { "If there's something I truly think is great then I buy it" } \\
\text { "I pay only for software I find worthy" } \\
\text { "There isn't much software I use frequently that is worth paying for" }\end{array}$ \\
\hline Buy software when financially able (4) & $\begin{array}{l}\text { "Hardly ever. And why should I. If I need it and can crack it then good for me" } \\
\text { "Never, I have no professional reason to do so, and as I am a student, very little money to ease my } \\
\text { conscience" } \\
\text { "Not often. I'm from a poor family" }\end{array}$ \\
\hline "I pay for software] whenever I have the money to do so" \\
"If I could afford it, I would pay for Windows and Visual Studio"
\end{tabular}

The responses to this question contain a great deal of variation that cannot be explained by demographics or group/scene affiliation. They are discussed in the following section.

Table 10: Tangible Benefits

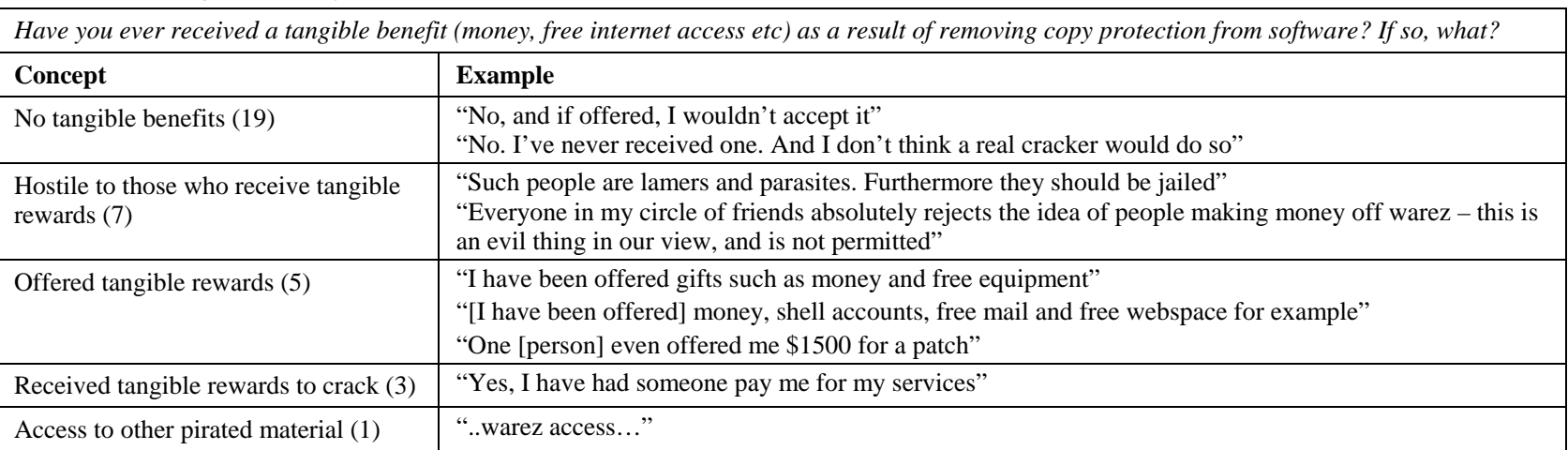

Tangible benefits do not influence the decision to crack software. Indeed, a significant proportion of respondents were openly hostile to the concept of people making money from cracking, perhaps supporting the existence of a personal credo by which crackers operate.

Table 11: Denial of Responsibility

\begin{tabular}{|l|l|}
\hline \multicolumn{2}{|l|}{ Does the threat of punishment affect your decision to continue cracking software? If so, how? } \\
\hline Concept & Example \\
\hline $\begin{array}{l}\text { Punishment has no effect } \\
\text { (11) }\end{array}$ & $\begin{array}{l}\text { "I fear nothing of punishment. Like Galileo expanded his knowledge despite the church, I do the same" } \\
\text { "No the threat doesn't affect me at all. And why should it?" }\end{array}$ \\
\hline $\begin{array}{l}\text { Threat of punishment } \\
\text { significantly influences } \\
\text { cracking (10) }\end{array}$ & $\begin{array}{l}\text { "It bothers me immensely that you could go to jail for cracking, longer than people go to jail for rape" } \\
\text { "Yes, been thinking a lot of retirement. I guess it's not worth it, to be busted and lose everything" } \\
\text { "Yes when [DrinkorDie] got busted we all got scared and some people quit" }\end{array}$ \\
\hline $\begin{array}{l}\text { Punishment threat concerns } \\
\text { but does not influence (6) }\end{array}$ & $\begin{array}{l}\text { "Maybe for } 5 \text { minutes sometimes, but it's a true hobby of min, it’s my life, I do it in ANY free time I have" } \\
\text { "Old habits are hard to break" } \\
\text { "I tried to quit numerous times but it's just not possible. You will lose many friends, the feeling when you break a } \\
\text { new protection and all other benefits the scene has to offer" }\end{array}$ \\
\hline $\begin{array}{l}\text { Punishment threat has } \\
\text { reverse effect (2) }\end{array}$ & $\begin{array}{l}\text { "If there was no threat of being caught, not many would bother cracking. It's the little kid syndrome, the more you } \\
\text { tell him not to, the more he does it" }\end{array}$ \\
\hline
\end{tabular}


Crackers have decided to pirate software with full control over their actions. Only two respondents noted people that could influence their software cracking. Almost half of the respondents stating the threat of punishment was ineffectual and the other half stating it had a significant effect.

Table 12: Denial of Injury

\begin{tabular}{|l|l|}
\hline Do you think that software companies suffer as a result of your actions? If so, in what capacity? \\
\hline Concept & Example \\
\hline Piracy hurts companies (11) & $\begin{array}{l}\text { "They only suffer if their product is good and worthy of payment" } \\
\text { "Of course they do. They lose millions because of [software piracy]" }\end{array}$ \\
$\begin{array}{l}\text { Piracy does not harm } \\
\text { software companies (6) }\end{array}$ & $\begin{array}{l}\text { "Companies are so rich that the piracy problem does not exist in their case." } \\
\text { "No. People who cannot afford their software will not buy it at all” } \\
\text { "No. Those who crack wouldn't have paid for the software anyway" }\end{array}$ \\
\hline Conflicted about effect (5) & "Software companies never, but maybe single authors who release their software independently..." \\
\hline $\begin{array}{l}\text { Piracy benefits companies } \\
\text { (3) }\end{array}$ & \begin{tabular}{l} 
"Some medium-sized firms say their sales went up after their software got cracked" \\
"Some surely benefit from the huge increase in customer base that can occur when a piece of software is widely \\
\hline
\end{tabular}
\end{tabular}

Most respondents can recognise the damage caused to software firms by their actions. There are others who even believe that their actions are beneficial.

Table 13: Denial of the Victim (Item 1)

\begin{tabular}{|l|l|}
\hline Does the size of a software company affect your decision to crack their software? Please explain your answer. \\
\hline $\begin{array}{l}\text { Category } \\
\text { software (12) }\end{array}$ & $\begin{array}{l}\text { Example } \\
\text { "Yes. We all like to release well known titles. When you release good well known software you get } \\
\text { more status! }\end{array}$ \\
\hline $\begin{array}{l}\text { Firm size does not affect decision to } \\
\text { pirate software (12) }\end{array}$ & $\begin{array}{l}\text { "No, not at all, I crack whatever I can get my hands on" } \\
\text { "Never, the software company has absolutely nothing to do with whatever I crack" }\end{array}$ \\
$\begin{array}{l}\text { Will not crack software from a 'small’ } \\
\text { firm (8) }\end{array}$ & $\begin{array}{l}\text { "It does not trouble me when cracking very expensive apps from big companies, as I don't think I am } \\
\text { "I try not to crack software made by poor students etc" } \\
\text { "Yes. The small companies are usually working on a shoestring budget. The multinationals, well, } \\
\text { they're a different kettle of fish..." }\end{array}$ \\
\hline $\begin{array}{l}\text { "Yill not crack software from a 'big' } \\
\text { firm (4) }\end{array}$ & $\begin{array}{l}\text { "I would not go crack something from Adobe, they got money and power, and god knows what they } \\
\text { would do" }\end{array}$ \\
\hline
\end{tabular}

Table 14: Denial of the Victim (Item 2)

What role do the actions of the software industry play in the popularity of pirated software nowadays?

\begin{tabular}{|c|c|}
\hline Concept & Example \\
\hline No Role (6) & $\begin{array}{l}\text { "I don't think the actions of the software industry play any role in the popularity of pirated software. People like free stuff, } \\
\text { and if their morals are at a certain level, they will use pirated software" } \\
\text { "I don't see they do anything [in the Internet piracy environment] except of course developing the software" } \\
\text { "They haven't got a role. If someone gets their hands on something unreleased it will get released. It's just a matter of time } \\
\text { and motivation" }\end{array}$ \\
\hline $\begin{array}{l}\text { Fix bad company } \\
\text { practices (5) }\end{array}$ & $\begin{array}{l}\text { "if a company decides not to offer free updates that provides a strong incentive to crack their application” } \\
\text { "Maybe if they protected their software a bit more then they wouldn’t have a problem” }\end{array}$ \\
\hline $\begin{array}{l}\text { Over-Pricing } \\
\text { effects (5) }\end{array}$ & $\begin{array}{l}\text { "I doubt Windows would have been pirated in this large scale if it was cheaper" } \\
\text { "How they can justify someone paying } \$ 1500 \text { for a CD is ridiculous" } \\
\text { "Companies demand too much for their products, that's why people use cracked stuff" } \\
\text { "High prices of software is the main reason why so many people use pirated software" }\end{array}$ \\
\hline $\begin{array}{l}\text { Morally corrupt } \\
\text { industry (2) }\end{array}$ & $\begin{array}{l}\text { "Should morally corrupt industry players attempt to crush the scene, it then becomes a game and they should expect a } \\
\text { fight. The more they fight the more I will crack those players' software" }\end{array}$ \\
\hline $\begin{array}{l}\text { Self-Destructed by } \\
\text { advertising piracy } \\
\text { (1) }\end{array}$ & $\begin{array}{l}\text { "The software and music industry have hurt themselves by making such a public issue out of file sharing clients like the } \\
\text { former Napster and Kazza. Prior to the Napster controversy, few people realized that you could obtain music and software } \\
\text { for free using these programs" }\end{array}$ \\
\hline
\end{tabular}

${ }^{\dagger}$ Five people signalled that they did not understand this question

Half of the responses indicate a lack of concern about the size of a software firm when cracking its software. The other half use different reasons for considering the firm's size. While eight responses indicate a wish to avoid harm to smaller software firms, the remaining four responses concerned fear of retribution. Five respondents believed that their actions help remedy bad corporate software practice. The same number believe that software pricing has lead to the proliferation of pirated software.

Table 15: Condemnation of the Condemners (Item 1)

What is your opinion of the reaction and response of the commercial software industry towards software piracy? 


\begin{tabular}{|c|c|c|}
\hline Concept & \multicolumn{2}{|l|}{ Example } \\
\hline $\begin{array}{l}\text { CSI (Commercial } \\
\text { Software Industry) have } \\
\text { the wrong priorities ( } 7 \text { ) }\end{array}$ & \multicolumn{2}{|c|}{$\begin{array}{l}\text { "Their reaction is wrong. They should make prices lower so that more people want to by a legal copy" } \\
\text { "Developers should learn how to protect their software better" } \\
\text { "They have made a mistake by making a public issue of the file-sharing clients" }\end{array}$} \\
\hline $\begin{array}{l}\text { The CSI reaction is } \\
\text { pointless (6) }\end{array}$ & \multicolumn{2}{|c|}{$\begin{array}{l}\text { "They don't get it. The more you fight it, the more people will get into it, there is never a shortage of people willing } \\
\text { to spend early in the morning hours of their time proving a point" } \\
\text { "They are plain stupid. Targeting P2P-users won’t lead anywhere" }\end{array}$} \\
\hline CSI ignore the issue (5) & \multicolumn{2}{|c|}{$\begin{array}{l}\text { "Big companies seem to completely ignore the issue of cracking, almost as if they do not believe it hurts profits" } \\
\text { "Do they react? I've rarely seen anything." }\end{array}$} \\
\hline CSI is appropriate (2) & \multicolumn{2}{|c|}{ "I support the [Business Software Alliance] as they mainly crack down on companies that use pirated software" } \\
\hline \multicolumn{3}{|c|}{$\begin{array}{l}{ }^{+} \text {One person signalled that they did not understand this question. } \\
\text { Table 16: Condemnation of the Condemners (Item 2) }\end{array}$} \\
\hline \multicolumn{3}{|c|}{ What is your opinion of the reaction and response of the law enforcement agencies towards software piracy? } \\
\hline \multicolumn{2}{|l|}{ Concept } & Example \\
\hline \multicolumn{2}{|c|}{ LEA actions are justified (6) } & $\begin{array}{l}\text { "They do their job, crackers are doing illegal actions” } \\
\text { "They have a job to do" } \\
\text { "Don't think they do anything wrong, they got the law on their side” }\end{array}$ \\
\hline \multicolumn{2}{|c|}{$\begin{array}{l}\text { Law Enforcement Agencies (LEA) have } \\
\text { overreacted (5) }\end{array}$} & $\begin{array}{l}\text { "Their penalties are completely disproportionate to the crimes...to bust them AND give them a } \\
\text { sentence comparable to manslaughter, is just outrageous" } \\
\text { "I think it’s overkill” }\end{array}$ \\
\hline \multicolumn{2}{|c|}{ LEA actions are misguided (4) } & $\begin{array}{l}\text { "Banning reverse-engineering will only cause a decline in computer security” } \\
\text { "If they actually understood why we crack then perhaps they’d employ us instead of putting us in jail” }\end{array}$ \\
\hline \multicolumn{2}{|c|}{ LEA response is Insignificant (4) } & “I’m always surprised there isn’t more of a response” \\
\hline
\end{tabular}

Seven respondents believe that the CSI reaction is incorrect while another six believe the CSI reaction is futile and has little effect on piracy. Six respondents accept the inevitability of LEA efforts to address software piracy. These responses indicate an acceptance that they are breaking the law as crackers. While some indicated that the LEA actions were justified, none deemed their actions appropriate.

Table 17: The Appeal to Higher Loyalties

\begin{tabular}{|l|l|}
\hline Is software piracy morally wrong? Please explain your answer. \\
\hline Concept & Example \\
\hline Ambivalent Attitude (13) & $\begin{array}{l}\text { "I struggle with the moral issues of piracy - I have tried, not entirely successfully, to find a morally justifiable set of } \\
\text { rules to follow" } \\
\text { "I think it’s a two sided story...it depends on how you define software piracy" } \\
\text { "Well not really, it depends on how you think about it". }\end{array}$ \\
\hline $\begin{array}{l}\text { Software firms are } \\
\text { morally wrong (8) }\end{array}$ & $\begin{array}{l}\text { "The big companies and the existing laws against [piracy] are morally wrong, and piracy only flourishes because of } \\
\text { "To unnecessary high prices for software" } \\
\text { full of bugs and poor programming yet provided to the public without a money back guarantee" }\end{array}$ \\
\hline $\begin{array}{l}\text { Piracy morally wrong (6) } \\
\text { wrong (4) }\end{array}$ & $\begin{array}{l}\text { "Well , I think yes, ppl make a lot of afford to create software , and then smart arses like us crack it ;D" } \\
\text { "Its basically stealing from people who work hard" }\end{array}$ \\
\hline $\begin{array}{l}\text { Only if it harms small } \\
\text { firms (4) }\end{array}$ & $\begin{array}{l}\text { "I don't think it is seen as morally wrong, no more than breaching copyright when we copy a cassette tape or record } \\
\text { "No. What we do with the software should be up to us" }\end{array}$ \\
\hline Only if for profit (3) & $\begin{array}{l}\text { "If you understand a budding developer, working for a long time on a program and seeing his months of work given } \\
\text { "If you are a company and use a software product to make money, then yes" }\end{array}$ \\
\hline
\end{tabular}

Six respondents indicated that cracking software is justified if the software is too expensive. Three believe that cracking software from a smaller firm is not justifiable and, surprisingly, three believe that the benefit to endusers is not justified at all. Most crackers had complex attitudes toward the morality of software piracy. Eight respondents attacked the morality of software firms and their pricing strategies.

\section{DISCUSSION AND CONCLUSIONS}

The findings, with respect to the study's research questions, were as follows.

1. What factors motivate software crackers to remove copy protection from commercial software?

While there is moderate support for the proposition that the social aspects of the cracking scene are highly rewarding, there is very strong support for the proposition that social participation is not a motivation factor. In the absence of a group environment, almost all (median 7, mean 6.33) respondents would continue cracking. Clearly there are other, more powerful, motivational factors if the respondents are so willing to continue cracking without the rewards offered by a social environment. The willingness of crackers to act anonymously suggests that recognition plays only a minor role in the motivation to crack software. The issue of receiving recognition for 
cracking software polarised the respondents (standard deviation 2.239, median 2.5). While most considered recognition unnecessary, some felt that receiving recognition was extremely important. There is little evidence of altruistic concerns in the motivation of crackers. Some crackers believed that individuals should pay for software that they use (median 6, mean 5.67).

Most respondents believe that the harder a piece of software is to crack, the more enjoyable the experience, and releasing the software was secondary to the challenge of cracking itself (median 7, mean 6.17). This finding may not apply to other members of the piracy process, such as couriers and suppliers, as their role is not as challenging as that of the crackers (Lee 2002). There is support (median 1.5, mean 2.21) for the proposition that crackers do not limit themselves to software that they personally need. That crackers believe that others should pay for software they use, while they themselves facilitate the use of pirated software is something of a paradox. There is insignificant support (median 1, mean 1.67) for tangible reward as a motivating factor. This suggests that some crackers apply different reasoning to choosing software to crack and to personally using cracked software. Respondents may be reluctant to use cracked software if they see merit in its purchase, if they have the money to purchase the software, or if they are one of the three who purchased all their software.

2. What factors do software crackers use to justify removing the copy protection from commercial software?

Disapproval of the software industry and law enforcement respectively has little influence on the decision to crack software. There is strong support for the argument that crackers accept full responsibility for their actions. While most respondents accepted that their actions as a cracker cause harm to the industry, some believe their actions are harmless, or are, at least, conflicted about the existence of adverse effects. However, some respondents did use the denial of injury to justify their actions.

Results for the denial of the victim indicate that, while the majority believe that the software industry does not deserve to have its products illegally copied, their actions as crackers are justified. Crackers may be capable of recognising targets they believe are inappropriate. While most crackers do not wish any harm on the software industry, some clearly felt that law enforcement agencies over-react in their interactions with crackers. Most respondents (median 2.5, mean 2.92) believed that inability to afford a piece of software should not be a barrier to using that software. Conversely, the majority of respondents (median 5, mean 4.54) also felt that people should pay for software. Some appealed to higher loyalties, in this case serving the community by supplying software, as a means of justifying their behaviour. However the conflicting results of this factor indicate that most crackers justify piracy depending on the situation.

The study is subject to important limitations. First, the small sample size limits the analysis. Factor analysis would have been useful in exploring whether respondents are using one technique or if a minority are using all techniques. The sample may not be representative of the cracker population. The survey was self-selective, and responses may not be generalisable beyond the respondent group (Simsek and Veiga 2001). Further, respondent desire for secrecy and non-repudiation may have prompted them to omit significant information. Surveys conducted at later times may give different results, especially in as dynamic an environment as the software market. Only crackers who read the relevant forums were included in the sample. The research factors were carefully chosen from the literature but may not be effective factor proxies.

Avenues for future research exist. More respondents would make the analysis more effective with more complex statistical analyses. A case-study approach could be employed using particular groups, such as the large groups that law enforcement agencies believe are responsible for $90 \%$ of the pirated software available on the Internet (US Customs 2001). Crackers exhibit complex decision-making procedures about the morality of software piracy, which suggests the use of a personal decision making code. Research into such a code is needed.

\section{REFERENCES}

Alderfer, C. (1969). “An Empirical Test of a New Theory of Human Needs” Organizational Behavior and Human Performance 4

Ashforth, B. E., Mael, F., (1989). “Social Identity Theory and the Organization” The Academy of Management Review 14(1)

Barber, R. (2001). “Hackers Profiled - Who Are They and What Are Their Motivations?” Computer Fraud \& Security 2001(2)

Barbuto, J. E., Scholl, R. W. (1998). "Motivation sources inventory: Development and Validation of New Scales to Measure an Integrative Taxonomy of Motivation” Psychological Reports 82: 1011-1022.

Barnard, C. (1938). The Functions of the Executive, Englewood Cliffs.

Cheyne, T., Ritter, F. (2001). “Targeting Audiences on the Internet” Communications of the ACM 44(4): 94-98.

Constant, D., L. Sproull, Keisler, S., (1996). “The Kindness of Strangers: The Usefulness of Electronic Weak Ties for Technical Advice” Organization Science 7(2): 119-135.

Deci, E. L. (1975). Intrinsic Motivation, New York, Plenum Press.

Dillman, D. (1978). Mail and Telephone Surveys: The Total Design Method, New York, John Wiley and Sons

Dubin, R. (1978). Theory Building, New York, Free Press.

Ford, M. E. (1992). Motivating Humans, Newbury Park, Sage Publications.

Galliers, D. (1992). Information Systems Research, Oxford, Blackwells. 
Gauthier, D. K. (2001). "Professional Lapses: Occupational Deviance and Neutralization Techniques in Veterinary Medical Practice” Deviant Behavior 22(6): 467-490.

Glass, R. S., Wood, W. A. (1996). "Situational Determinants of Software Piracy: An Equity Theory Perspective” Journal of Business Ethics 15(11): 1189-1198.

Gopal, R. D., Sanders, G. L. (1998). "International Software Piracy: Analysis of Key Issues and Impacts" Information Systems Research 9(4): 380-397.

Gopal, R. D., Sanders, G. L. (2000). “Global Software Piracy: You Can't Get Blood From A Turnip” Communications of the ACM 43(9): 82-89.

Highland, H. J. (1984). Protecting Your Microcomputer System, New York, Wiley.

Katz, D., Kahn, R. L. (1966). The Social Psychology of Organizations, New York, John Wiley \& Sons.

Kotulic, A. G., Clark, J. G. (2004). "Why There Aren't More Information Security Research Studies” Information \& Management, (41:5), 597 - 607

Lee, J. (2002). “Pirates on the Web, Spoils on the Street” The New York Times. 11 July 2002: 1.

Lim, V. K. G. (2002). "The IT Way of Loafing on the Job: Cyberloafing, Neutralizing and Organizational Justice” Journal of Organizational Behavior 23: 675-694.

Limayem, M., M. Khalifa, Chin, W., (1999). “Factors Motivating Software Piracy: A Longitudinal Study”. Proceedings of the 20th International Conf. Information Systems.

Loch, K., Conger, S. (1996). “Evaluating Ethical Decision Making and Computer Use” Communications of the ACM 39(7)

Locke, E. A. (1968). “Toward a Theory of Task Motivation and Incentives” Organizational Behavior and Human Performance 3

Malhotra, M. K., Grover, V. (1998). “An Assessment of Survey Research in POM: From Constructs to Theory” Journal of Operations Management 16(4): 407-425.

Maslow, A. H. (1943). “A Theory of Human Motivation” Psychological Review 50: 370-396.

Maude, T. Maude, D. (1984). "Hardware Protection Against Software Piracy” Communications of the ACM 27(9): 950-959.

McClelland, D. C. (1961). The Achieving Society, Princeton, Van Nostrand.

Moore, P. (2003). "Steal this Disk: Copy Protection, Consumers' Rights, and the Digital Millennium Copyright Act” Northwestern University Law Review 97(3): 1437-1470.

Nosek, B. A., M. R. Banaji, Greenwald, A. G., (2002). "E-research: Ethics, Security, Design, and Control in Psychological Research on the Internet” Journal of Social Issues 58(1): 161-176.

Piazza, P. (2002). "Law Enforcement Targets Warez Sites” Security Management 46(3): 34.

Pierce, M. A., Henry, J. W. (1996). “Computer Ethics: The Role of Personal, Informal, and Formal Codes” Journal of Business Ethics 15: 425-437.

Schildkraut, J. S., Gasper, J. (2000). “Copy-protection System for Photographic Paper” Journal of Electronic Imaging 9(4)

Simpson, P. M., D. Banerjee, Simpson, C. L., (1994). “Softlifting: A Model of Motivating Factors” Journal of Business Ethics 13: 431-438.

Simsek, Z., Veiga, J., (2001). “A Primer on Internet Organizational Surveys” Organizational Research Methods 4(3): 218-235.

Smith, M. A., Leigh, B. (1997). "Virtual Subjects: Using the Internet as an Alternative Source of Subjects and Research Environment” Behavior Research Methods, Instruments and Computers 29: 496-505.

SIIA (2000). SIIA's Report on Global Software Piracy 2000

Solomon, S. L., O'Brien, J. (1991). "The Effect of Demographic Factors on Attitudes Toward Software Piracy". Ethical Issues in Information Systems. Dejoie, R., Fowler, G. Paradice. D., Boyd \& Fraser. 168-181.

Straub, D. (1989). "Validating Instruments in MIS Research” MIS Quarterly 13(2): 147-169.

Sykes, G. M., Matza, D. (1957). “Techniques of Neutralization: A Theory of Delinquency” American Sociological Review 22(6)

US Customs (2001). “U.S. Customs Dismantles One of the World's Most Sophisticated Internet Piracy Networks”, US Customs Press Release, Dec. 11, 2001

Vernon, M. D. (1969). Human Motivation, Cambridge, Cambridge University Press.

\section{COPYRIGHT}

Sam Cruise, Sigi Goode (C) 2004. The authors assign to ACIS and educational and non-profit institutions a nonexclusive licence to use this document for personal use and in courses of instruction provided that the article is used in full and this copyright statement is reproduced. The authors also grant a non-exclusive licence to ACIS to publish this document in full in the Conference Papers and Proceedings. Those documents may be published on the World Wide Web, CD-ROM, in printed form, and on mirror sites on the World Wide Web. Any other usage is prohibited without the express permission of the authors. 